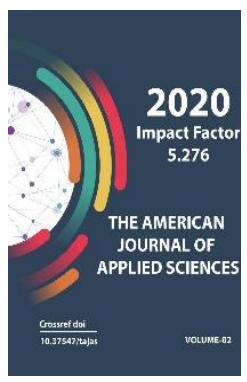

Copyright: Original content from this work may be used under the terms of the creative commons attributes 4.0 licence.

\section{Parasitic Phytonematodes Of Pomegranate Agrocenosis Of Southern Regions Of Uzbekistan}

\author{
Abdujabbor Sattorovich Bekmurodov \\ Doctor Of Philosophy In Biology (PhD), Senior Lecturer, Department Of Zoology, Termez \\ State University, Termez, Uzbekistan \\ Masuma Umarovna Raxmatova \\ Senior Lecturer, Department Of Zoology, Termez State University, Termez, Uzbekistan
}

\title{
ABSTRACT
}

The article provides data on the fauna and distribution of parasitic phytonematodes of pomegranate agrocenoses in the southern regions of Uzbekistan. The study revealed 30 parasitic species (22 ectoparasitic and 8 endoparasitic) of phytonematodes belonging to 2 orders, 8 families and 12 genera. It is defined that around root soil and root system of pomegranate plant are met such species as Longidorus elongatus, Xiphinema opisthohysterum, Tylenchorhynchus cylindricus, Bitylenchus dubius, Quinisulcius capitatus, Merlinius brevidens, Rotylenchus robustus, Helicotylenchus dihystera, $\mathrm{H}$. erythrinae, Paratylenchus hamatus, Pratylenchus pratensis, Meloidogyne incognita, M. javanica and Ditylenchus dipsaci.

\section{KEYWORDS}

Pomegranate agrocenocic, parasitic phytonematodes, ectoparasitic perforators, endoparasitic perforators, root system, rhizosphere.

\section{INTRODUCTION}

In Uzbekistan, a historical center of horticulture and viticulture, the oldest varieties of apricot, almond, quince, grapes, as well as valuable varieties of Apple, pear, peach, pomegranate and other fruit plants are grown.
Of the valuable and medicinal subtropical fruit crops, pomegranates, like many others, are affected by various pests and diseases, including phytonematodes, and these parasites cause huge damage to the crop of these crops. Therefore the study of 
nematodofauna pomegranate agriculture, to determine bio-ecological peculiarities of parasitic species, which occupy an important place in solving economic and social problems in the Republic of Uzbekistan, primarily in solving the problem of providing the population with high-quality and diverse food, but also in getting valuable products for pharmaceutical, perfumery, leather, paint and other industries.

On the territory of Central Asia, parasitic species of cultivated and wild pomegranate were first studied by Sh. Kh. Khurramov [4, p. 146-157; 5, 333 p.].

\section{MATERIALS AND METODS}

In order to study the species composition and distribution of parasitic phytonematodes of pomegranate agrocenoses in the period from 2009-2019, we collected phytonematodes from the root soil and root system of plants in 34 shirkat farms from 18 districts of Surkhandarya and Kashkadarya regions of the Republic. The research was carried out using the generally accepted route method [3, p. 3-11.].

During the phytohelminthological study, 1700 soil and root system samples of pomegranate plants were collected and analyzed. Phytonematodes were extracted by the Berman funnel method and fixed with $4 \%$ formalin solution. Nematode enlightenment was performed in a mixture of glycerol and alcohol (1:3) and permanent preparations on glycerol were prepared for laboratory processing of the material using the Seinhorst method [6, p. 57-69]. Soil samples for the presence of a cyst-forming nematode were usually analyzed using the standard Dekker method [1, 445 p.]. Preparations for determining the types of gall nematodes were prepared according to the well-known method of E. S. Kiryanova And E. L. Krall [2, 447 p.].

\section{RESULTS AND DISCUSSIONS}

As a result of phytohelminthological studies in pomegranate agrocenoses of the southern regions of Uzbekistan, we found 30 species of parasitic phytonematodes belonging to 12 genera, 8 families, and 2 orders. Of these, 30 species have been recorded in the basal soil, and 24 species in the root system of plants.

\section{Ectoparasitic perforators}

In our material, they are represented by 5 families (Longidoridae, Xiphinematidae, Dolichodoridae, Hoplolaimidae, Paratylenchidae), 9 genera (Longidorus, Xiphinema, Tylenchorhynchus, Bitylenchus, Quinisulcius, Merlinius, Rotylenchus, Helicotylenchus, Paratylenchus) and 22 species.

Longidorus elongatus was found in the rhizosphere of pomegranate plants in the Kitab district of Kashkadarya region.

Xiphinema basiri is found in the rhizosphere of pomegranate plants in the Angora district of Surkhandarya region.

$X$. elongatum was found in the rhizosphere of pomegranate plants in the Angora district of Surkhandarya and Karshi district of Kashkadarya region.

X. pachtaicum has been recorded in the roots and rhizosphere of pomegranate plants in the Angora region of Surkhandarya region.

$X$. opisthohysterum is found in the roots and rhizosphere of pomegranate plants in the Jarkurgan and Angora districts of Surkhandarya region. This species is registered in the fauna of Uzbekistan for the first time.

Tylenchorhynchus cylindricus was found in the root system and basal soil of pomegranate 
plants in Kitab, Yakkabag, and Karshi districts of Kashkadarya region.

T. brassicae was found in the roots and rhizosphere of pomegranate plants in Karshi and Shakhrisyabz districts of Kashkadarya region.

T. clayton was found in the roots and rhizosphere of pomegranate plants in Yakkabag district of Kashkadarya region.

Ditylenchus dubius was in the root system and rhizosphere soil of plants of pomegranate in Shurchi region, Baysun, Denau, Kumkurgan, Saryassiya, Jarkurgan, Myzrabad, Angora areas and Surkhandarya, Karshi, Yakkabag, Kitab districts of Kashkadarya region.

Quinisulcius capitatus is found in the roots and rhizosphere of pomegranate plants in the Muzrabad and Angora districts of Surkhandarya region.

Merlinius brevidens is found in the roots and rhizosphere of pomegranate plants in Kitab, Yakkabag, and Shakhrisyabz Districts of Kashkadarya region.

Rotylenchus robustus was found in the roots and rhizosphere of pomegranate plants in Kitab, Yakkabag, and Karshi districts of Kashkadarya region.

R. goodeyi was registered in the rhizosphere of pomegranate plants in Baysun district of Surkhandarya region.

Helicotylenchus dihystera has been recorded in the roots and rhizosphere of pomegranate plants in the Termez, Angora districts of Surkhandarya and Shakhrisyabz, Karshi, Yakkabag, Kitab districts of Kashkadarya region.

H. digitiformis was found in the roots and rhizosphere of pomegranate plants in Kitab,
Yakkabag, and Karshi districts of Kashkadarya region.

$\mathrm{H}$. digonicus was found in the roots and rhizosphere of pomegranate plants in Angora district of Surkhandarya and Karshi, Yakkabag, and Kitab districts of Kashkadarya region.

$\mathrm{H}$. erythrinae has been recorded in the roots and rhizosphere of pomegranate plants in the Shurchi, Baysun, Altynsay, Kumkurgan, Saryassiya, Sherabad, Termez, Muzrabad, Angora districts of Surkhandarya and Karshi, Yakkabag, Kitab districts of Kashkadarya region.

$H$. multicinctus is found in the root system and basal soil of pomegranate plants in the Angora district of Surkhandarya region.

H. pseudorobustus is found in the roots and rhizosphere of pomegranate plants in the Jarkurgan and Angora districts of Surkhandarya region.

H. varicaudatus is found in the roots and rhizosphere of pomegranate plants in the Kitab district of Kashkadarya region.

Paratylenchus bukowinensis is registered in the rhizosphere of pomegranate plants in Kitab, Shakhrisyabz district of Kashkadarya region.

P. hamatus is registered in the rhizosphere of pomegranate plants in Jarkurgan, Termez, Muzrabad, Angora districts of Surkhandarya region.

Endoparasitic perforators. In our research, they are represented by 3 families (Pratylenchidae, Meloidogynidae, Anguinidae), 3 genera (Pratylenchus, Meloidogyne, Ditylenchus), and 8 species.

Pratylenchus pratensis has been recorded in the roots and rhizosphere of pomegranate 
plants in the Shurchinsky, Baysun, Denau, Altynsay, Kumkurgan, Saryassiya, Bandykhan, Jarkurgan, Termez, Muzrabad, Angora districts of Surkhandarya and Karshi, Yakkabag, Kitab districts of Kashkadarya region.

P. crenatus were identified in the roots and the rhizosphere of pomegranate plants in Kitab, Yakkabag, Karshi districts of Kashkadarya region.

P. manohari detected in the rhizosphere of pomegranate plants in Yakkabag, Kitab district of Kashkadarya region.

P. neglectus was the roots and the rhizosphere of pomegranate plants in Kitab, Karshi districts of Kashkadarya region.

P. penetrans was found in roots and the rhizosphere of pomegranate plants in Karshi, Yakkabag, Kitab district of Kashkadarya region.

Meloidogyne incognita was detected in the roots and rhizosphere of pomegranate plants in Uzun, Denau, Jarkurgan, Sherabad, Angora districts of Surkhandarya and Karshi, Yakkabag, Kitab districts of Kashkadarya region.

M. javanica was registered in the roots and rhizosphere of pomegranate plants in Angora districts of Surkhandarya region.

Ditylenchus dipsaci is found in the roots and rhizosphere of pomegranate plants in Altynsay, Saryassiya, Uzun, Termez, Angora districts of Surkhandarya and Karshi, Yakkabag, Kitab districts of Kashkadarya region.

\section{CONCLUSION}

During studies from ectoparasitic perforators, the species $X$. opisthohysterum, T. cylindricus, T. brassicae, T. claytoni, B. dubius, Q. capitatus,
M. brevidens, R. robustus, $H$. dihystera, $H$. digitiformis, $H$. digonicus, $H$. erythrinae, P. bukowinensis, and $P$. hamatus were identified in numerous specimens in the roots and rhizosphere of pomegranate plants. The ectoparasitic perforators were dominated by the species $P$. pratensis, $P$. crenatus, $P$. penetrans, $M$. incognita, $M$. javanica, and $D$. dipsaci.

Results of phytohelminthological studies have shown that the above-mentioned detected species are phytohelminths with a specific pathogenic effect, which they cause serious diseases of pomegranate plants and cause great economic damage to fruit growing in Uzbekistan. Therefore, the study of the species composition, bioecological features of parasitic phytonematodes of pomegranate agrocenoses, especially the rationale for integrated measures to control these dangerous pests, is of great scientific and practical importance.

\section{REFERENSES}

1. Dekker H. Nematodes of plants and the fight against them. - M. Kolos, 1972. $445 \mathrm{p}$.

2. Kiryanova E. S., Krall E. L. Parasitic nematodes of plants and measures to control them. - Moscow: Nauka, 1969. - Vol. 1. 447 p.

3. Paramonov A. A. On some fundamental issues of phytohelminthology // In the book: Collection of works of young phytohelminthologists. - Moscow: 1958. - P. 3-11.

4. Khurramov Sh. Kh. To the spread of parasitic nematodes of plants southern Uzbekistan // In the book: Phytohelminthological research. - M.: 1978. - L. Ed. Nauka, - P. 146-157. 
5. Khurramov Sh. Kh. Nematodes of subtropical fruit crops of Central Asia and measures to control them // Tashkent. Ed., Fan. 2003. - 333 p.

6. Seinhorst J.W. A rapid method for the transfer of nematodes from fixative to anhydrous glycerin // Nematologica. 1959. V. 4, № 1. P. 67-69. 